\title{
Eradicating invasive rodents from wet and dry tropical islands in Mexico
}

\author{
Araceli Samaniego-Herrera, Alfonso A guirre-Muñoz \\ Yuliana Bedolla-Guzmán, Ana Cárdenas-Tapia, María Félix-Lizárraga \\ Federico Méndez-Sánchez, Orlando Reina-Ponce \\ Evaristo Rojas-MAYORAL and Flor TORRES-GARCía
}

\begin{abstract}
Eradications of invasive rodents from tropical islands have a lower success rate compared to temperate islands. In the tropics the wide range of physical and biological conditions results in a wide variety of island biomes, with unique challenges and windows of opportunity for rodent eradications. We describe and compare research and operational details of six successful eradications of invasive mice Mus musculus and ship rats Rattus rattus carried out during 2011-2015. The work was conducted on six islands in two distinct tropical archipelagos in Mexico (one dry in the Gulf of Mexico; one wet in the Caribbean), and included the first eradication of rats from a mangrove-dominated island $>500$ ha. Invasive rodent populations varied among species and islands, even neighbouring islands; overall density was higher on wet islands. Physical and biological features, including the presence of land crabs, determined eradication timing and rates of bait broadcast (higher on wet islands). An interval of 6-10 days between the two bait applications per island was sufficient to eradicate actively breeding mouse and rat populations. Impacts on non-target species were negligible, including those on wild and captive iguanas. Eradication success was rapidly confirmed based on ground monitoring and statistical modelling. Rodent eradications on larger tropical islands should be achievable with directed research to inform planning and implementation.
\end{abstract}

Keywords Eradication, invasive rodents, land crabs, Mexico, non-target impacts, restoration, tropical island

Supplementary material for this article can be found at https://doi.org/10.1017/So030605316001150

\footnotetext{
Araceli Samaniego-Herrera* (Corresponding author), Alfonso AguirreMuñoz, Yuliana Bedolla-Guzmán, Ana Cárdenas-Tapia, María FélixLizárraga, Federico Méndez-Sánchez, Evaristo Rojas-Mayoral and Flor Torres-García Grupo de Ecología y Conservación de Islas, A.C., Moctezuma 836, Zona Centro, Ensenada, Baja California, Mexico, C.P. 22800 E-mail araceli.samaniego@islas.org.mx

Orlando Reina-Ponce Asociación Veterinaria de Reptiles y Anfibios, Puebla, Mexico

*Also at: Pacific Invasives Initiative, University of Auckland, Private Bag 92019, Auckland 1142, New Zealand. E-mail ara.samaniego.mx@gmail.com

Received 8 June 2016. Revision requested 29 July 2016.

Accepted 8 September 2016. First published online 9 February 2017.
}

\section{Introduction}

Tnvasive mammals are the primary driver of biodiversity loss in island ecosystems (Towns et al., 2013). Of the four invasive rodent species of major concern (the Polynesian rat Rattus exulans, the ship rat $R$. norvegicus, the black rat $R$. rattus and the house mouse Mus musculus; Amori \& Clout, 2003), two are particularly widespread in the tropics: the ship rat and the house mouse (Singleton \& Krebs, 2007; Harper \& Bunbury, 2015). Ship rats are the most damaging invasive rodent to island ecosystems (Towns et al., 2006; Shiels et al., 2014), and are therefore the most frequently targeted species for eradication (Howald et al., 2007; DIISE, 2016). On islands where house mice are the only invasive mammal they can also have devastating, ecosystem-changing effects (Angel et al., 2009), and they have been targeted for eradication on islands all over the world (DIISE, 2016).

The $>600$ attempts at rodent eradication on islands worldwide (Russell \& Holmes, 2015) reflect the wide use of this type of conservation intervention as one of the most efficient actions to restore island ecosystems (Jones et al., 2016). Overall, rat eradication using toxic bait has had a high global success rate (89.4\%; Russell \& Holmes, 2015). However, the failure rates of eradications on tropical (18.8\%) vs nontropical islands (8.5\%) suggest that some aspects of successful operations in the tropics are not well understood. Improving the success rate on tropical islands is crucial, as the region includes priority sites with high numbers of species threatened by invasive rodents (Keitt et al., 2015).

Tropical island ecosystems range from simple unvegetated systems to seasonal forests and evergreen rainforests, despite their narrow latitudinal range (Osborne, 2000). Large tropical islands can even contain microcosms with contrasting physical and biological conditions, and understanding how these conditions influence invasive rodent ecology and non-target populations is key to eradication planning (Harper et al., 2015). To improve the success rate of rodent eradications in the tropics, and based on current knowledge, best practice guidelines for rat eradication on tropical islands were published by an international team (Keitt et al., 2015). Simultaneously, the probability of rat eradication success was evaluated according to three categories of tropical islands: savannah (dry), seasonal forest, 
and tropical rainforest (wet), and wet islands were found to be the most challenging (Russell \& Holmes, 2015). Within the wet category, mangrove-dominated islands, which are evergreen and permanently or regularly flooded, are particularly challenging for rodent eradication (Harper et al., 2014; Samaniego-Herrera et al., 2014; Harper \& Bunbury, 2015).

Mexico has a history of successfully eradicating diverse invasive mammal species from islands (Aguirre-Muñoz et al., 2011). Invasive rodents have been eradicated from 15 islands of 3-539 ha (Samaniego-Herrera et al., 2011, 2015), including the largest rat eradication on a wet tropical island to date, which is described here. The inherent challenges of the tropics (e.g. land crabs and year-round-breeding rodent populations) have been faced and resolved in implementing pest eradication projects on Mexico's numerous tropical islands. As conservation organizations require robust scientific knowledge and evidence to implement successful conservation programmes (Samaniego-Herrera et al., 2014), the organization Grupo de Ecología y Conservación de Islas has worked for 18 years to conduct systematic eradications to restore Mexico's islands. Together with research, seabird restoration and biosecurity, there have been 58 mammal eradications on 37 islands (Aguirre-Muñoz et al., 2016). Here we describe research and compare the operational details of six successful rodent eradication operations led by the organization across two contrasting Mexican tropical archipelagos (one dry, one wet).

\section{Study area}

The two archipelagos to which the study islands belong are Arrecife Alacranes in the Gulf of Mexico and Banco Chinchorro in the Caribbean Sea (Fig. 1, Table 1). Both have high marine and terrestrial biodiversity and are natural protected areas under Mexican federal law: Arrecife Alacranes as a National Park and Banco Chinchorro as a Biosphere Reserve (CONANP, 2000, 2006). Both are also Man and the Biosphere sites and Ramsar sites. The following descriptions are mainly from CONANP $(2000,2006)$.

Arrecife Alacranes is a coral atoll comprising five small (1.5-29 ha), flat, sandy keys (henceforth dry islands), three of which had invasive rodents in 2010 (Table 1 ). The climate is subtropical dry semi-arid, $\mathrm{BS} 1 \mathrm{w}(\mathrm{w})$; the mean annual temperature is $26.7^{\circ} \mathrm{C}$ and rainfall is scarce (annual mean $445 \mathrm{~mm}$ ) and concentrated in summer, resulting in low phenological variation in plants (Bonet \& Rzedowski, 1962). The open scrub community of halophytic plants is dominated by Suriana maritima and Tournefortia gnaphalodes. The most ubiquitous invertebrates are three species of land crabs; breeding vertebrate species include two lizards, three marine turtles and nine seabirds, the latter numbering several hundred (Leucophaeus atricilla, Thalasseus sandvicensis, Sula leucogaster) or thousand (Sula dactylatra, Anous stolidus,
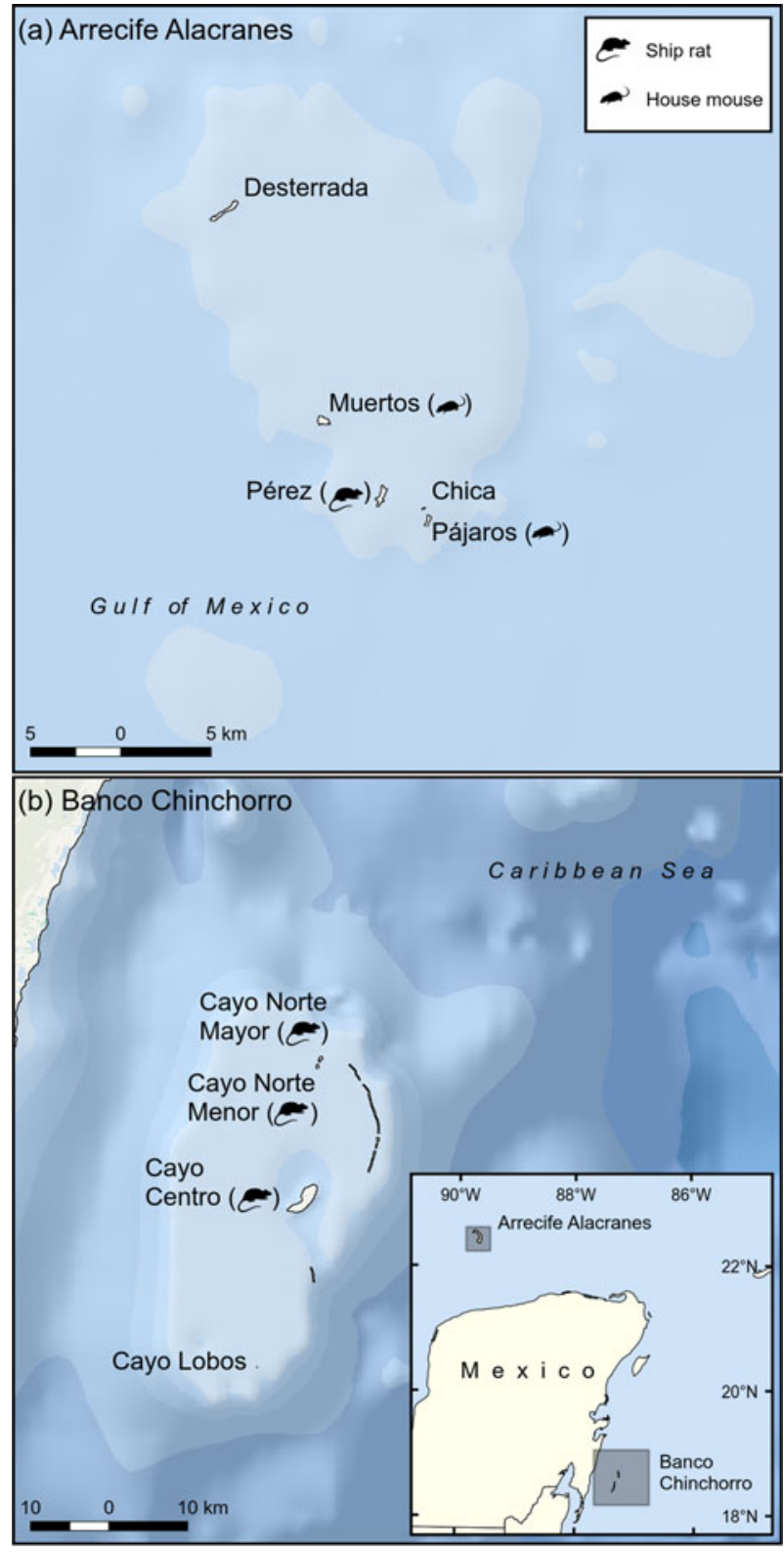

FIg. 1 Location of Arrecife Alacranes (a coral atoll) and Banco Chinchorro Islands (a false atoll), Mexico, and their invasion status in 2010. By 2015 all islands were free of invasive mammals.

Onychoprion fuscatus) pairs (Tunnell \& Chapman, 2000). In addition, terrestrial migratory birds are frequent visitors (Supplementary Table $\mathrm{S}_{1}$ ). Invasive rodents have been recorded on Pérez since 1699 (Fosberg, 1962). Pérez is the only island that is continually altered by human activity, which started in 1899 with the construction of a lighthouse and continues today, with a small permanent settlement (Table 1). Seasonal tourism is concentrated on Pérez.

Banco Chinchorro is a false atoll comprising four flat keys (o.5-539 ha; henceforth wet islands), three of which had invasive rodents in 2010 (Table 1). The climate is wet tropical, Aw2 ( $\left.\mathrm{x}^{\prime}\right)$, with a mean annual temperature of $26.5^{\circ} \mathrm{C}$. There is rainfall (annual mean $1,450 \mathrm{~mm}$ ) throughout the year but it is 
TABLE 1 Characteristics of the islands in the Arrecife Alacranes (dry) and Banco Chinchorro (wet) archipelagos, in Mexico (Fig. 1), where six rodent eradications were carried out during 2011-2015, with area, ecosystem type, dominant vegetation, number of residents, and species eradicated.

\begin{tabular}{|c|c|c|c|c|c|}
\hline Island & Area (ha) & Ecosystem type & Dominant vegetation & No. of residents & Species eradicated \\
\hline \multicolumn{6}{|l|}{ Arrecife Alacranes } \\
\hline Pájaros & 3 & Tropical dry & Short shrubs \& grasses & None & Mus musculus \\
\hline Pérez & 13 & Tropical dry & Tall shrubs \& herbaceous plants & 15 & Rattus rattus \\
\hline Muertos & 15 & Tropical dry & Short shrubs \& herbaceous plants & None & Mus musculus \\
\hline \multicolumn{6}{|l|}{ Banco Chinchorro } \\
\hline Cayo Norte Menor & 15 & Tropical wet & Mangroves & None & Rattus rattus \\
\hline Cayo Norte Mayor & 30 & Tropical wet & Mangroves \& evergreen forest & 10 & Rattus rattus \\
\hline Cayo Centro & 539 & Tropical wet & Mangroves \& evergreen forest & Up to 100 & Rattus rattus ${ }^{*}$ \\
\hline
\end{tabular}

${ }^{\star}$ Feral cats Felis catus were also eradicated (by trapping in 2010-2014).

concentrated in the summer and winter, with March usually being the driest month. The islands are covered with mangroves (Rhizophora mangle, Laguncularia racemosa, Avicennia germinans and Conocarpus erectus) and typical Caribbean tropical trees (dominated by Thrinax radiata, Bursera simaruba and Tournefortia gnaphalodes); introduced coconut palms Cocos nucifera are also widespread. Three species of land crabs have been recorded; breeding vertebrates include abundant populations of the American crocodile Crocodylus acutus, three lizard species, two iguanas, one gecko and only one seabird (Fregata magnificens). Most terrestrial and aquatic birds are migratory (Supplementary Table S2). Rodents probably invaded as a result of shipwrecks during the 16th century. The two largest islands have been directly and continually altered by human activity, beginning in the 1960 s (Table 1). Feral cats Felis catus were present only on the largest island and were eradicated by Grupo de Ecología y Conservación de Islas during 2010-2014 (Aguirre-Muñoz et al., 2016).

\section{Methods}

High precautionary standards were adopted to avoid the accidental introduction and distribution of invasive and pathogenic organisms. Separate teams were working simultaneously across the islands during the eradication operations, each with its own camping and research equipment, thus avoiding contamination. Provisions were delivered in secured containers, and insect and rodent traps were set in boats and store rooms, both on the islands and in our base on the mainland. Capture and handling techniques, for both native and invasive alien species, conformed to high standards of animal welfare (NOM, 2014).

\section{Rodent monitoring}

Preliminary work, which consisted of directed trapping and searches for signs of rodents, the use of chew-blocks and camera traps, and interviews, confirmed there was only one rodent species per island. Further monitoring was conducted to collect ecological information on the target rodent populations (e.g. population density and reproduction) to inform the eradication plan, and to estimate spatial detection parameters to inform the monitoring to confirm eradication. Live trapping was conducted systematically across islands, in both archipelagos simultaneously, two or three times per year for $1-5$ years before each eradication (Fig. 2). Each trapping session lasted 7-10 consecutive nights. On each island a grid of $10 \times 5$ points, $10 \mathrm{~m}$ apart, was set and permanently marked. At each point a live trap (either from Tomahawk Live Trap, Hazelhurst, USA, or H. B. Sherman, Tallahassee, USA) was set and baited each afternoon, and checked and closed each morning. Tomahawk traps baited with peanut butter were used to trap ship rats, and Sherman traps baited with oats were used to trap house mice. All traps were elevated above the ground by placing them on top of plastic containers to avoid interference from land crabs while still being accessible to juvenile rodents (A. Samaniego-Herrera, pers. obs.).

All rodents caught were marked with monel ear tags, and we recorded their age (adult or juvenile, based on genitalia), sex, standard body-size metrics (weight and head-body length) and reproductive condition (determined by the position of the testes in males, and the prominence of nipples in females) before releasing them at their capture point. Population parameters (density, sigma $(\sigma)$ and g0) were estimated using maximum-likelihood spatially explicit capture-recapture models implemented with package SECR in $R$ v. 2.15 (R Development Core Team, 2013).

\section{Eradication planning and implementation}

Each archipelago was a separate project, each managed by Grupo de Ecología y Conservación de Islas in coordination with federal government agencies. For each project a costbenefit analysis determined the best bait delivery option to deliver sufficient bait to every rodent territory and achieve 


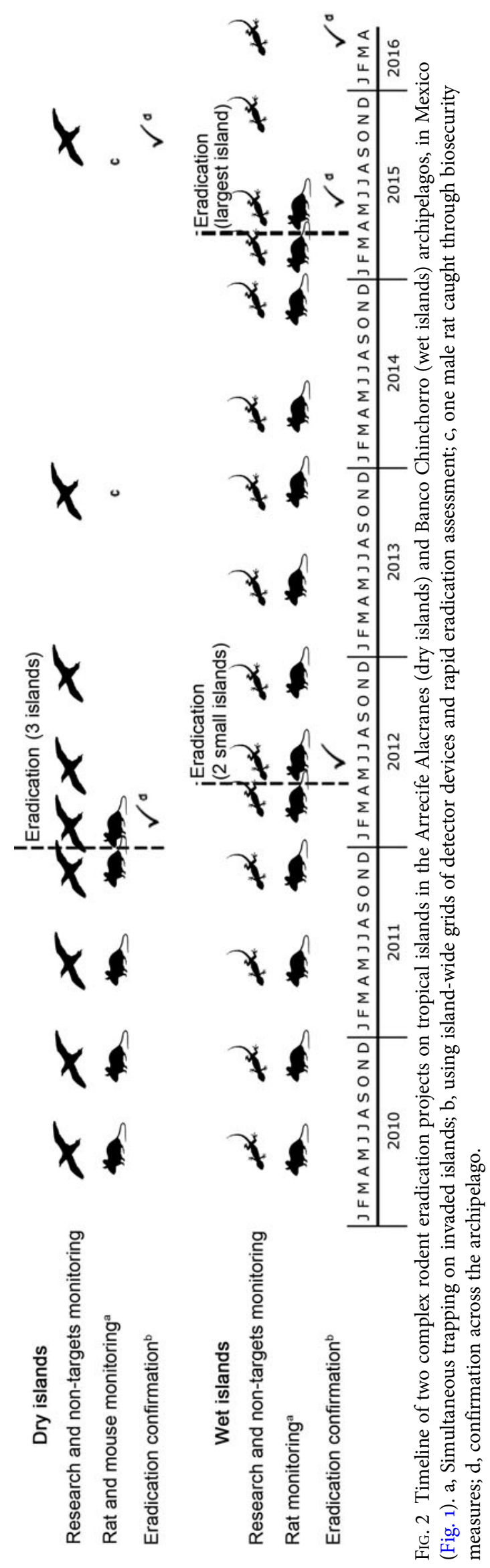

eradication. Such analyses included helicopter cost (international and national travel, daily rate, fuel and permits), cost and potential risks of ground-based operations (based on island size and accessibility), and local capacity (of both trained staff and partners).

The bait used was the rodenticide CI-25 (Conservation-25D in USA), developed by Bell Laboratories (Madison, USA) specifically for ecological restoration operations. CI-25 consists of green, unwaxed, compressed grain, $2 \mathrm{~g}$ pellets containing $25 \mathrm{ppm}$ brodifacoum (second-generation anticoagulant). We used both the original version of the bait, designed for dry environmental conditions, and a newer version (Conservation-25W in USA) resistant to high humidity (Wegmann et al., 2012). The use of the original version on the dry islands meant that leftover bait pellets on the ground would be broken down relatively quickly by physical and biological agents. However, using the newer version for the wet islands was crucial to ensure that the bait pellets retained their shape for several days in the humid environment. On the wet islands, $30 \mathrm{~g}$ bait blocks ( $25 \mathrm{ppm}$ brodifacoum), also by Bell Laboratories, were used. All bait batches contained the biomarker pyranine, which facilitates the detection of bait consumption across a wide range of invertebrates and vertebrates.

All dry islands were treated by hand broadcast of bait (Broome et al., 2011), given their small size and easy accessibility, and the relatively high cost of aerial broadcast. Evenness in bait coverage was particularly important where house mice were being targeted, and was achieved by distributing bait along a $5 \times 5 \mathrm{~m}$ grid. This higher-than-usual level of accuracy was also desired for the purpose of monitoring bait consumption, which was reported elsewhere as part of a meta-analysis (Pott et al., 2015). To plan and track the operation, a $50 \mathrm{~cm}$ resolution WorldView2 satellite image was used. In contrast, all wet islands were treated using the aerial broadcast technique (Broome et al., 2014) because of their larger size and complexity (Supplementary Fig. S1 shows details for Cayo Centro). The project was conducted in two phases: two simultaneous eradications on the smaller islands ( 15 and 30 ha) as a learning phase (including extensive research), and a later eradication on the largest island ( $539 \mathrm{ha}$ ), with an improved approach and a more experienced team, as the completion phase. Bait was broadcast from a helicopter using a spreader bucket purchased from Helicopters Otago Ltd (Mosgiel, New Zealand). To obtain accurate geographical data, the helicopter (Bell 206 Jet Ranger, Aspen Helicopters, Oxnard, USA) was equipped with a differential global positioning system (TracMap, Mosgiel, New Zealand). To track the aerial work and map bait densities on the ground, a $60 \mathrm{~cm}$ resolution Quickbird satellite image was used. Maps were produced using a geographical information system to confirm that bait distribution and application rates conformed with the planned strategy 
(Supplementary Fig. S2 shows details for Cayo Centro). In addition, for the largest operation (in 2015) we used a novel method to evaluate the aerial work (the Numerical Estimation of Rodenticide Dispersal model), which improves the accuracy of results by modelling more parameters (e.g. helicopter speed) and speeds up the process of identifying bait gaps (Rojas-Mayoral et al., 2016).

Bait uptake experiments conducted in dry seasons (Pott et al., 2015) were useful for determining bait application rates, and also took into account the type (hermit vs burrowing) and abundance of land crabs on each island (A. Samaniego-Herrera, unpubl. data). Bait application rates for the dry islands, where hermit crabs are dominant, were lower than the rates for the wet islands (Table 2), which host abundant populations of large burrowing crabs. For all six islands, two bait applications 6-10 days apart were planned (Table 2), and a detailed hand broadcast was conducted along the shore after each main application. On the dry islands this shore application was done on foot by walking along open sandy beaches on the same day as the main bait application. By hand broadcasting bait, the distribution of sufficient bait for the rodents was ensured while minimizing the risk of bait being washed out at high tide. On the wet islands, which have permanently flooded, mangrovevegetated shores, the shore application was a sub-project in itself and required teams working simultaneously on foot and in boats and kayaks. This work involved navigating around dense mangrove forests, including patches in interior lagoons, and took 2 full days after each main bait application. Bait was delivered along the shore in the form of bait blocks attached to the mangrove branches every $50-100 \mathrm{~m}$, because of the flooded terrain on all wet islands (Supplementary Fig. $\mathrm{S}_{3}$ shows details for Cayo Centro). To achieve even coverage of bait in a timely and safe manner (e.g. avoiding crocodile nests), a mobile app (the Field Reporting and Navigation app) was designed to facilitate navigation and speed up reporting. For the islands with human settlements (Cayo Centro, Cayo Norte Mayor and Pérez), bait stations (1-4 per $50 \mathrm{~m}^{2}$ ) filled with bait blocks were set inside and underneath constructions, as well as around piers.

Climate and reproductive cycles of both target and native species are the main factors to be considered for timing rodent eradications. On the dry islands the climatic window of opportunity was significantly larger, as most of the year is dry and windy, which explains the low seasonal fluctuation in plant phenology (Bonet \& Rzedowski, 1962), land crab activity (A. Samaniego-Herrera, unpubl. data) and rodent biology, including reproduction (Samaniego-Herrera, 2014), all confirmed during the planning phase. Thus, other factors, such as bird and turtle nesting and human activities such as tourism, which ideally should be avoided, were the main determinants of eradication timing. On the contrary, climate was the most important factor for the timing of eradications on the wet islands. Research on target
TABLE 2 Comparison of successful approaches used to eradicate rodents from dry (Arrecife Alacranes) and wet (Banco Chinchorro) tropical islands in Mexico (Fig. 1) during 2011-2015.

\begin{tabular}{|c|c|c|}
\hline & Dry islands & Wet islands \\
\hline $\begin{array}{l}\text { Range in monthly } \\
\text { rainfall }(\mathrm{mm})\end{array}$ & $4-95$ & $16-278$ \\
\hline Dry season & November-July & February-April \\
\hline $\begin{array}{l}\text { Month of rodent } \\
\text { eradication }\end{array}$ & December (2011) & $\begin{array}{l}\text { April (2012), March } \\
\text { (2015) }\end{array}$ \\
\hline $\begin{array}{l}\text { Main bait } \\
\text { competitors }\end{array}$ & Small hermit crabs & Large burrowing crabs \\
\hline $\begin{array}{l}\text { Max. abundance of } \\
\text { crabs }\end{array}$ & Medium & High \\
\hline $\begin{array}{l}\text { Fluctuation of crab } \\
\text { activity }\end{array}$ & Low & High \\
\hline $\begin{array}{c}\text { Main baiting } \\
\text { technique }\end{array}$ & Hand broadcast & Aerial broadcast \\
\hline Bait version* & Conservation-25D & Conservation-25W \\
\hline $\begin{array}{l}\text { No. of bait } \\
\text { applications }\end{array}$ & 2 & 2 \\
\hline $\begin{array}{l}\text { Days between } \\
\text { applications }\end{array}$ & 6 & 7 (2012), 10 (2015) \\
\hline $\begin{array}{l}\text { Bait application } \\
\text { rate (first }+ \text { second } \\
\text { application) }\end{array}$ & $12+5 \mathrm{~kg} \mathrm{ha}^{-1}$ & $\begin{array}{l}30+12 \mathrm{~kg} \mathrm{ha}^{-1} \\
(2012), 30+30 \mathrm{~kg} \\
\mathrm{ha}^{-1}(2015)\end{array}$ \\
\hline
\end{tabular}

${ }^{\star}$ Details in Methods

and non-target species confirmed that operating in the dry season would significantly decrease interference by bait competitors (mainly land crabs), maximize the likelihood of rodents being food-stressed (although breeding activity never ceases), and minimize non-target impacts by avoiding the peak of bird migration (Samaniego-Herrera et al., 2014; GECI, 2015).

\section{Mitigating non-target impacts}

On the dry islands, where birds are seasonally abundant and reptiles are naturally scarce, as evidenced by their low abundance on the two rodent-free islands (Grupo de Ecología y Conservación de Islas, unpubl, data), impacts on native fauna were minimized by operating in winter, thus avoiding activity peaks of nesting seabirds, turtles and terrestrial migratory birds. Masked boobies Sula dactylatra and frigatebirds Fregata magnificens were nesting in low numbers (both eggs and chicks were recorded) on both mouse-infested islands, and the last few turtle hatchlings of the season emerged days before the eradication.

On the wet islands, where reptiles are diverse and abundant and birds are usually present in low numbers, black Ctenosaura similis and green iguanas Iguana iguana were kept in captivity because their susceptibility to brodifacoum was undetermined and preliminary experiments had confirmed their interest in the bait. In addition, iguana presence was artificially high around the human settlements 
TABLE 3 Median and 95\% credible intervals (CI) of estimated probability of rodent eradication from dry (Arrecife Alacranes) and wet (Banco Chinchorro) tropical islands in Mexico (Fig. 1), using island-wide grids of detector devices and the rapid eradication assessment model. All islands were evaluated twice: 1 month or earlier after baiting (in bold), and 14 months or later after baiting (during visits conducted for research purposes).

\begin{tabular}{|c|c|c|c|c|c|}
\hline \multirow[b]{2}{*}{ Island } & \multirow[b]{2}{*}{ No. of months after first bait application } & \multirow[b]{2}{*}{ No. of nights of monitoring } & \multicolumn{3}{|c|}{ Probability of success } \\
\hline & & & Median & Lower CI & Upper CI \\
\hline \multicolumn{6}{|c|}{ Dry islands (Arrecife Alacranes) } \\
\hline \multirow[t]{2}{*}{ Muertos } & 0.5 & 15 & 0.96 & 0.91 & 0.98 \\
\hline & 48 & 5 & 1.00 & 1.00 & 1.00 \\
\hline \multirow[t]{2}{*}{ Pájaros } & 0.5 & 20 & 0.98 & 0.91 & 0.99 \\
\hline & 48 & 5 & 1.00 & 1.00 & 1.00 \\
\hline \multirow[t]{2}{*}{ Pérez } & 0.5 & 20 & 0.98 & 0.92 & 0.99 \\
\hline & 48 & 5 & 1.00 & 1.00 & 1.00 \\
\hline \multicolumn{6}{|c|}{ Wet islands (Banco Chinchorro) } \\
\hline \multirow[t]{2}{*}{ Cayo Centro } & 1 & 25 & 0.93 & 0.87 & 0.98 \\
\hline & 14 & 10 & 0.96 & 0.99 & 1.00 \\
\hline \multirow[t]{2}{*}{ Cayo Norte Mayor } & 0.5 & 21 & 0.93 & 0.85 & 0.98 \\
\hline & 36 & 10 & 1.00 & 1.00 & 1.00 \\
\hline \multirow[t]{2}{*}{ Cayo Norte Menor } & 0.5 & 21 & 0.94 & 0.87 & 0.99 \\
\hline & 36 & 10 & 1.00 & 1.00 & 1.00 \\
\hline
\end{tabular}

for reasons of commensalism, and the risk of iguanas interfering with the eradication operation was determined to be high, because of their potentially excessive bait consumption around human settlements (i.e. creating gaps in bait coverage). A total of 153 black and 136 green iguanas were caught by hand a few days before each eradication operation (only around human settlements), individually marked, and kept in captivity (in situ) until the bait had disappeared from the ground. They were then released following a health check. Additional iguanas (12 on Cayo Norte Mayor and 39 on Cayo Centro) were marked, checked for health and released immediately (i.e. before bait application) for monitoring purposes. All marked iguanas (340 wild and captive individuals on two islands) were also monitored 6 months and 1 year after the eradications. Professional reptile handlers managed the entire iguana subproject, including the construction of appropriate facilities and the management of the iguanas' diet (Supplementary Material 1).

\section{Post-eradication monitoring}

Island-wide monitoring was conducted for 6 weeks following the first bait application on each island. Diurnal and nocturnal surveys (4-8 person-hours per day) were conducted daily to search for, collect and dissect fresh vertebrate carcasses. Bait consumption was checked through biomarker signs (fluorescent green colour under UV light) and dissections.

\section{Evaluating eradication efficacy}

Rodent absence was evaluated within weeks after each operation (Table 3) using the rapid eradication assessment model, a novel spatial-survey model that quantitatively estimates the probability of eradication success, using a grid of detection devices across an island and parameters obtained from prior rodent monitoring (Table 4; Russell et al., 2017). The model was originally developed to confirm the 2009 rat eradication on Isabel Island, Mexico (Samaniego-Herrera et al., 2013), and since then Grupo de Ecología y Conservación de Islas has used this tool systematically to confirm mouse and rat eradications. The spacing of the confirmation grid on all three dry islands was $50 \mathrm{~m}$, whereas on the two smaller and the largest wet islands the grid was 75 and $150 \mathrm{~m}$, respectively (Supplementary Fig. $\mathrm{S}_{4}$ shows the grid on Cayo Centro).

Additionally, radio-telemetry was used to monitor rodent time to death during the eradications, as such information is scarce for tropical environments. One week before the first bait application on each island, 13-30 adult rodents (balanced sex ratio) were trapped in dispersed locations, fitted with radio-collars and monitored daily to make sure they were alive on the day of the first bait application and to investigate how long afterwards they remained active.

\section{Results}

Rodent monitoring We confirmed only one rodent species was present on each island in 2010 (M. musculus on two dry islands and $R$. rattus on one dry and all three wet islands; Table 1). Rodent data were analysed in detail by Samaniego-Herrera (2014) and the main results relevant to eradication planning are in Table 4. Overall, significant 
TABLE 4 Biological data from two invasive rodent species, Mus musculus and Rattus rattus, on dry (Arrecife Alacranes) and wet (Banco Chinchorro) tropical islands in Mexico (Fig. 1).

\begin{tabular}{|c|c|c|}
\hline & Dry islands & Wet islands \\
\hline \multicolumn{3}{|l|}{ Mus musculus } \\
\hline \multirow[t]{2}{*}{ Population density (mice ha ${ }^{-1}: 95 \% \mathrm{CI}$ ) } & Muertos: 4.1-30.9 & \\
\hline & Pájaros: 18.9-76.1 & \\
\hline \multirow[t]{2}{*}{ Weight (g; mean $\pm S D)$} & Muertos: $17.6 \pm 2.8(n=29)$ & \\
\hline & Pájaros: $13.9 \pm 2.3(\mathrm{n}=142)$ & \\
\hline \multirow[t]{2}{*}{ Parameter g0 $0^{1}(95 \% \mathrm{CI})$} & Muertos: $0.04-0.07$ & \\
\hline & Pájaros: 0.08-0.14 & \\
\hline \multirow[t]{2}{*}{ Parameter $\sigma^{2}(95 \% \mathrm{CI})$} & Muertos: $20.46-34.63$ & \\
\hline & Pájaros: 14.62-24.75 & \\
\hline \multicolumn{3}{|l|}{ Rattus rattus } \\
\hline \multirow[t]{2}{*}{ Population density (rats ha ${ }^{-1}: 95 \% \mathrm{CI}$ ) } & Pérez: $6.3-32.7$ & Cayo Norte Mayor: 25.3-102.5 \\
\hline & & Cayo Centro: $6.5-47.9$ \\
\hline \multirow[t]{2}{*}{ Weight (g: mean $\pm S D$ ) } & Pérez: $174.0 \pm 42.3(\mathrm{n}=90)$ & Cayo Norte Mayor: $189.0 \pm 42.6(n=228)$ \\
\hline & & Cayo Centro: $154.9 \pm 26.7(\mathrm{n}=125)$ \\
\hline Parameter g0 $0^{1}$ (95\% CI) & Pérez: $0.07-0.10$ & $0.05-0.07$ \\
\hline Parameter $\sigma^{2}(95 \% \mathrm{CI})$ & Pérez: 20.21-23.17 & $14.33-22.69$ \\
\hline
\end{tabular}

${ }^{1}$ The probability of detection when trap and range centres coincide

${ }^{2}$ The spatial scale of the detection function

TABLE 5 Approximate cost (USD), per item, of the principal phases of the rodent eradications implemented in Arrecife Alacranes and Banco Chinchorro archipelagos, in Mexico (Fig. 1).

\begin{tabular}{|c|c|c|c|c|}
\hline & \multicolumn{2}{|c|}{ Arrecife Alacranes ${ }^{1}$ ( 3 dry islands; 31 ha) } & \multicolumn{2}{|c|}{ Banco Chinchorro $^{2}$ (3 wet islands; 584 ha) } \\
\hline & $\begin{array}{l}\text { Eradication } \\
\text { implementation }\end{array}$ & $\begin{array}{l}\text { Post-eradication surveys } \\
\text { (2 visits) }\end{array}$ & $\begin{array}{l}\text { Eradication } \\
\text { implementation }\end{array}$ & $\begin{array}{l}\text { Post-eradication surveys } \\
\text { (2 visits) }\end{array}$ \\
\hline Preparation \& planning ${ }^{3}$ & 43,545 & & 42,348 & \\
\hline Helicopter & Not applicable & & 202,695 & \\
\hline Aerial bucket & Not applicable & & Already owned & \\
\hline Bait & 22,581 & & 124,025 & \\
\hline Boat expenses & 2,196 & & 4,526 & \\
\hline Staff & 126,538 & 7,500 & 190,790 & 22,500 \\
\hline Food, travel, fuel, materials & 64,615 & 4,643 & 113,902 & 3,840 \\
\hline $\begin{array}{l}\text { Lodging, air transportation, } \\
\text { ground transportation }\end{array}$ & 34,231 & 1,786 & 79,528 & 1,232 \\
\hline Field equipment \& materials & 62,462 & 1,071 & 130,969 & 755 \\
\hline Total & 356,168 & 15,000 & 888,783 & 28,327 \\
\hline
\end{tabular}

${ }^{1}$ All three islands were treated simultaneously in 2011.

${ }^{2}$ Two islands were treated simultaneously in 2012, and a third island was treated in 2015 .

${ }^{3}$ Includes work shown in Fig. 2.

differences in rodent size and population density were found between species and among islands, including neighbouring islands; for example, the lowest population density was recorded for house mice on the dry island of Muertos (8 $\mathrm{ha}^{-1}$ ), whereas the highest density was recorded for ship rats on the wet island of Cayo Norte Mayor $\left(66 \mathrm{ha}^{-1}\right)$; however, the maximum rat density on nearby Cayo Centro $\left(25 \mathrm{ha}^{-1}\right)$, where cats were present until recently, was closer to that of the dry island of Pérez $\left(19 \mathrm{ha}^{-1}\right)$.

Eradication planning and implementation Rodent eradication operations were carried out in December 2011 on the three dry islands, and in April 2012 and March 2015 on the two smaller and the largest wet island, respectively. Each project (i.e. on each archipelago) required 2-5 years of research and preparation (legal, financial and logistical; Fig. 2). The main difference in cost between projects resulted from bait quantity and helicopter use on the wet islands (Table 5). As planned, two bait applications were implemented on each island, 6-10 days apart, using contrasting bait application rates between dry $\left(17 \mathrm{~kg} \mathrm{ha}^{-1}\right)$ and wet (42-6o $\mathrm{kg} \mathrm{ha}^{-1}$ ) islands (Table 2; Supplementary Fig. S2 shows details for Cayo Centro). A team of $17-28$ people was required for each operation, which consisted of a core team of experienced practitioners (Grupo de Ecología y Conservación de Islas staff) plus partners and volunteers, who 
received appropriate training. For the dry islands the total effort required to spread bait twice manually across the islands (31 ha in total) was 860 person-hours, with 207 person-hours required for setting markers. Forty-seven bait stations were set around human settlements $(20-50 \mathrm{~m}$ spacing). For the wet islands the total flying time required to aerially spread bait twice across the islands ( 584 ha in total) was $28.24 \mathrm{~h}$. In addition, 677 person-hours were required for placing bait blocks in the mangroves; 145 bait stations (20-50 m spacing) were set around human settlements.

Mitigating non-target impacts The iguanas caught around the human settlements on Cayo Centro and Cayo Norte Mayor (289 in total) were kept in captivity for 4 weeks in 2012 and for 6 weeks in 2015. Survival rates in captivity were 98.4\% $(n=129)$ and $96.9 \%(n=160)$, respectively. Three weeks after the first bait application $94 \%(n=51)$ of wild iguanas (i.e. those exposed to the bait) were alive and displayed normal behaviours. Three wild iguanas, in addition to two untagged iguanas, were found dead 2-3 weeks after the first bait application. The cause of death was probably a combination of primary poisoning and poor health, given that in addition to bait, plastic bags were found in their stomachs during dissection. No more carcasses were found by Grupo de Ecología y Conservación de Islas staff or the island residents during the next 12 months. The tags were not always readable after 6 months, and therefore the presence of some individuals could not be confirmed. However, 12 months after baiting we estimated $>90 \%$ of the surviving tagged iguanas were alive, based on morphometric data and population counts (GECI, unpubl. data).

Post-eradication monitoring On the three dry islands, within 6 weeks of the first bait application we collected a total of 101 vertebrate carcasses (17 on Pájaros, 28 on Muertos and 56 on Pérez), all of which were birds. Of these, $74 \%$ (belonging to seven species) were positive for the biomarker, indicating bait consumption and showing signs of poisoning. The remaining 26\% (belonging to 12 species) were negative for the biomarker and showed signs of starvation (Table 6). The majority of the carcasses were found along the shore, where bait pellets were highly visible against the white sand. On the wet islands we collected a total of 16 vertebrate carcasses (seven on Cayo Norte Mayor and nine on Cayo Centro). Of these, $69 \%$ (belonging to four species) were positive for the biomarker and showed signs of poisoning, and the remaining $31 \%$ (belonging to seven species) were negative for the biomarker.

Evaluating eradication efficacy The island-wide grids of detection devices were active for 15-25 consecutive nights, commencing 2-3 weeks after each first bait application.
The rapid eradication assessment model indicated a high probability of success (93-98\%) immediately after each eradication operation (Table 3). Subsequent visits for research purposes provided an opportunity for further testing, and this work confirmed rodent absence 1-4 years after baiting (Table 3; Fig. 2). Most collared rodents ( $80-85 \%$ on each island) were located and recovered; the remaining rodents may have had faulty collars or may have died near the ocean and been washed away. The first collared rodent died on day 3 after the first bait application and the last died on day 12. Dissections confirmed poisoning as the cause of death in all of the recovered rodents (96).

\section{Discussion}

All six rodent eradication operations were planned and implemented by Grupo de Ecología y Conservación de Islas using the same scientific approach. Important operational differences between dry and wet ecosystems, such as bait application rates and treatment of island perimeters, reflect inherent differences in ecological biomes rather than management preferences. Although aerial bait dispersal was always preferable, bait broadcast methods varied between dry and wet islands because of economic constraints. Operating during the dry season was also preferred, as challenges such as land crab interference, floods, and arboreal rat activity are augmented during the wet season, particularly on wet islands (Samaniego-Herrera et al., 2014). For example, during a bait uptake experiment conducted on Cayo Centro in late May, at the beginning of the wet season, when most land crabs are active, $50 \mathrm{~kg} \mathrm{ha}^{-1}$ of placebo bait disappeared overnight (A. Samaniego-Herrera, unpubl. data). This is $>10$ times higher than the mean daily consumption $\left(4.7 \mathrm{~kg} \mathrm{ha}^{-1}\right)$ recorded in the same plot during the dry season (GECI, 2015). The substantial decrease in land crab activity during the short dry season, rather than the moderate fluctuation in rat density, is the main cause of decreased bait consumption.

Balancing disturbance effects and eradication efficacy in the tropics is challenging, as the potentially high bait rates required considerably increase the potential for negative impacts on native species (Pitt et al., 2015) and increase the cost of eradication campaigns. On temperate islands a total bait rate of $12 \mathrm{~kg} \mathrm{ha}^{-1}$ is commonly used for rodent eradications (Broome et al., 2014), whereas in the tropics the bait rate varies considerably and can be substantially higher (Pott et al., 2015). For example, a total bait rate of $160 \mathrm{~kg} \mathrm{ha}^{-1}$ was used in the eradication of rats from Palmyra Atoll (Wegmann et al., 2012). In comparison, the total bait rates used in our campaigns are conservative and related to island category (17 $\mathrm{kg} \mathrm{ha}^{-1}$ on the dry islands and $42-60 \mathrm{~kg} \mathrm{ha}^{-1}$ on the wet islands). The apparent differences between dry and wet islands warrant further investigation. In terms of cost, 
TABLE 6 Details of carcasses found during monitoring of non-target species within 6 weeks after bait application during rodent eradications on three dry (Arrecife Alacranes; 31 ha total area) and three wet (Banco Chinchorro; 584 ha total area) tropical islands in Mexico (Fig. 1).

\begin{tabular}{|c|c|c|c|c|}
\hline \multirow[b]{2}{*}{ Species } & \multicolumn{2}{|c|}{ Dry islands (No. of individuals) } & \multicolumn{2}{|c|}{ Wet islands (No. of individuals) } \\
\hline & $\begin{array}{l}\text { With signs of bait } \\
\text { consumption }^{1}\end{array}$ & $\begin{array}{l}\text { With signs of } \\
\text { starvation }^{2}\end{array}$ & $\begin{array}{l}\text { With signs of bait } \\
\text { consumption }^{1}\end{array}$ & $\begin{array}{l}\text { With signs of } \\
\text { starvation }^{2}\end{array}$ \\
\hline \multicolumn{5}{|l|}{ Birds } \\
\hline $\begin{array}{l}\text { Ruddy turnstone Arenaria } \\
\text { interpres }\end{array}$ & 21 & 2 & & \\
\hline Cattle egret Bubulcus ibis & & 1 & & \\
\hline Sanderling Calidris alba & 38 & 4 & & \\
\hline $\begin{array}{l}\text { Swainson's thrush Catharus } \\
\text { ustulatus }\end{array}$ & & & & 1 \\
\hline Little blue heron Egretta caerulea & & & 1 & 1 \\
\hline $\begin{array}{l}\text { Magnificent frigatebird Fregata } \\
\text { magnificens }\end{array}$ & & 1 & & \\
\hline American coot Fulica americana & & 2 & & \\
\hline Herring gull Larus argentatus & 1 & 1 & & \\
\hline Sooty tern Onychoprion fuscatus & & 4 & & \\
\hline $\begin{array}{l}\text { Northern waterthrush Parkesia } \\
\text { noveboracensis }\end{array}$ & & & & 1 \\
\hline $\begin{array}{l}\text { Savannah sparrow Passerculus } \\
\text { sandwichensis }\end{array}$ & 11 & & & \\
\hline Blue grosbeak Passerina caerulea & & & & 1 \\
\hline $\begin{array}{l}\text { Brown pelican Pelecanus } \\
\text { occidentalis }\end{array}$ & & 1 & & \\
\hline $\begin{array}{c}\text { Double-crested cormorant } \\
\text { Phalacrocorax auritus }\end{array}$ & & 3 & & \\
\hline $\begin{array}{l}\text { Black-bellied plover Pluvialis } \\
\text { squatarola }\end{array}$ & 1 & 1 & & \\
\hline $\begin{array}{l}\text { Great-tailed grackle Quiscalus } \\
\text { mexicanus }\end{array}$ & & & 3 & \\
\hline $\begin{array}{l}\text { Yellow-rumped warbler } \\
\text { Setophaga coronata }\end{array}$ & 2 & & & \\
\hline $\begin{array}{l}\text { Palm warbler Setophaga } \\
\text { palmarum }\end{array}$ & 1 & 1 & & \\
\hline Yellow warbler Setophaga petechia & & & & 1 \\
\hline Masked booby Sula dactylatra & & 5 & & \\
\hline \multicolumn{5}{|l|}{ Reptiles } \\
\hline Black iguana Ctenosaura similis & & & 5 & 1 \\
\hline Green iguana Iguana iguana & & & 2 & 1 \\
\hline
\end{tabular}

${ }^{1}$ Positive for biomarker and signs of internal haemorrhage

${ }^{2}$ Negative for biomarker

the eradication budget reported here is well below the average for similar projects worldwide (Holmes et al., 2015).

We believe the detailed work on the perimeter of the wet islands was crucial to eradication success; however, we recognize it may not be feasible to apply this manual method on larger islands. We therefore encourage the development of more efficient alternatives (e.g. aerial methods) so that larger mangrove islands can be cleared of invasive rodents (Harper et al., 2014). The use of the Conservation-25W bait for these particularly wet islands proved to be useful, as reported previously for Palmyra Atoll, as this bait is significantly more resistant to humidity (Wegmann et al., 2012) than the original version (Conservation-25D). On the dry islands the high visibility of the green bait pellets on the white sandy beaches may have contributed to the higherthan-expected consumption by non-target species. Future projects should consider reducing the bait spread on large, sandy, unvegetated beaches, or using bait stations in this type of habitat.

Although the aerial broadcast of bait is the preferred option for conducting rodent eradications on islands (Broome et al., 2014), hand broadcasting of bait is an appropriate alternative when suitable pilots and helicopters are not readily available at a reasonable cost, provided the size and complexity of the island are manageable (i.e. efficiencies of scale for cost are absent). Regardless of the broadcast technique, avoiding gaps and ensuring the even distribution of bait are essential. 
In this case all dry islands were small and close together, and therefore implementing three operations simultaneously maximized management and research efficiency and minimized cost and the risk of re-invasion. Wet islands proved to be more challenging, not only because of their size but also because of the complexity and novelty of the habitat (Harper et al., 2015). Until 2010 only one small wet island ( $2 \mathrm{ha}$ ) with a comparable percentage of mangrove cover had been subjected to a rodent eradication (Wegmann et al., 2008). We agree with Harper et al. (2015) that the problem mangroves pose for large-scale eradications on wet islands is confounded by the lack of knowledge of rat ecology in mangroves.

For both mouse-infested dry islands combined, the mean weight $(14.5 \pm$ SD $2.8 \mathrm{~g})$ and density $\left(13 \mathrm{ha}^{-1}\right)$ of house mice were lower than those reported for temperate islands (Russell, 2012). For rats, overall densities were higher on wet islands (maximum $66 \mathrm{ha}^{-1}$ ) and values are well within the range reported for tropical islands, which in turn are higher than on temperate islands (Shiels et al., 2014; Harper \& Bunbury, 2015). Both invasive rodent species reproduce year-round on dry and wet islands.

The casualties of the eradication campaigns included individuals of 11 native species, of which the majority were birds, including common carnivorous shorebirds, such as ruddy turnstones Arenaria interpres and sanderlings Calidris alba, which was unexpected given their regular feeding habits. No boobies or frigatebirds, which were nesting at the time, were harmed by the eradication operations, in line with findings for Isabel Island (Samaniego-Herrera et al., 2014). Likewise, reptiles in general appeared to have low susceptibility to brodifacoum, as previously suggested (Harper et al., 2011; Broome et al., 2012), given that scats with bait signs were commonly found but carcasses were comparatively rare. Temporary captivity of commensal iguanas was a successful approach to avoid gaps in bait coverage around primary rat habitat near human settlements. However, captivity measures may not be necessary as long as the reptile populations are healthy, as low mortality, much lower than in birds, is expected.

The evaluation of eradication success shortly after implementation through robust statistical modelling using rapid eradication assessment was invaluable. Given the experimental approach of these conservation projects undertaken in high-risk, poorly understood tropical ecosystems (Russell \& Holmes, 2015), the confirmation provided by rapid eradication assessment improved decision making for each subsequent operation, representing an overall saving in eradication costs. Local and real-time parameters from each target population were obtained through research conducted alongside management efforts, at low cost, and used in the confirmation analysis. The results are the first examples of the confirmation of successful rodent eradication within weeks of baiting, and were verified opportunistically during subsequent research trips to the islands. Rapid eradication assessment is therefore a powerful tool for accelerating the confirmation of eradication, especially on small $(<100 \mathrm{ha})$, accessible islands (Russell et al., 2017). Given the generalist diet of the eradicated rodent populations (Samaniego-Herrera, 2014), a wide range of native plant, invertebrate and vertebrate populations (including land crabs and seabirds) are expected to recover as a result of rodent removal.

Continued funding, with long-term vision from committed foundations, has been essential to successful eradication efforts. As of 2015, 37 Mexican islands have been cleared of invasive mammals, $40 \%$ of which have been rodent eradications (Aguirre-Muñoz et al., 2016). Long-term, effective island biosecurity is now being developed as a collaborative national programme. International collaboration has also been important, with support from countries with extensive mammal eradication experience, such as New Zealand (Towns et al., 2013; Russell \& Broome, 2016).

Our general approach to rodent eradication (Samaniego-Herrera et al., 2014) is consistent with international best practice guidelines (Keitt et al., 2015), although we have some comments on these guidelines based on our experience with programmes on Mexican islands. In particular, it is increasingly clear that most invasive rodent populations on both wet and dry tropical islands breed all year round, but this is not a precursor to eradication failure. We have demonstrated that 6-10 days between bait applications, which is the norm in Mexico (Samaniego-Herrera et al., 2011, 2014), is sufficient to eradicate actively breeding mouse and rat populations from tropical islands, and this short period between applications can result in significant operational savings. Although land crabs are mentioned in the guidelines, we emphasize that understanding this community could be the difference between failure and success in rodent eradication campaigns in the tropics. It is also imperative to over-monitor tropical islands until sufficient information has been accumulated to achieve results comparable to those on temperate islands. The six rodent eradications reported here, including that on Cayo Centro, the largest wet tropical island cleared of invasive rodents, were achieved by over-engineering the projects.

\section{Acknowledgements}

This work is part of the National Island Restoration Programme of Grupo de Ecología y Conservación de Islas. We are grateful to Nic Tolentino for developing the FERN app. The projects reported here were funded through national and international collaborations. We thank our donors (Packard Foundation, Marisla Foundation, Comisión Nacional para el Conocimiento y Uso de la Biodiversidad, Global Environment Facility, United Nations Development 
Programme, Alianza WWF-Fundación Carlos Slim, Fondo Mexicano para la Conservación de la Naturaleza, U.S. Fish and Wildlife Service, National Fish and Wildlife Foundation), partners (Secretaría de Medio Ambiente y Recursos Naturales (SEMARNAT), Secretaría de Marina Armada de México, Secretaría de Gobernación, Comisión Nacional de Áreas Naturales Protegidas (CONANP), Secretaría de Comunicaciones y Transportes, Amigos de Sian Ka'an, Bell Laboratories, Aspen Helicopters and Auckland University), project reviewers (Biodiversity Restoration Specialists and the Island Eradication Advisory Group, New Zealand Department of Conservation), Juan Carlos Gómez-Juárez for looking after the iguanas, Pierre Charruau for sharing crocodile nest locations, and Nuno Simoes, his students and all the volunteers and island residents for their contributions, James Russell, Jenny Daltry and an anonymous referee for their useful comments, and Andrea Liévana MacTavish for revising the English. Research on native and invasive species and eradication of invasive rodents protocols were approved by the Mexican Ministry of Environment (Dirección General de Vida Silvestre-SEMARNAT). All projects were conducted in collaboration with the National Protected Areas Commission (CONANP-SEMARNAT).

\section{References}

Aguirre-Muñoz, A., Samaniego-Herrera, A., Luna-Mendoza, L., Ortiz-Alcaraz, A., Méndez-Sánchez, F. \& HeRnÁndeZ-MontoyA, J. (2016) La restauración ambiental exitosa de las islas de México: Una reflexión sobre los avances a la fecha y los retos por venir. In Experiencias mexicanas en la restauración de los ecosistemas (eds E. Ceccon \& C. Martínez-Garza), pp. 487-512. UNAM, CRIM, UAM \& CONABIO, Cuernavaca, Mexico.

Aguirre-Muñoz, A., Samaniego-Herrera, A., Luna-Mendoza, L., Ortiz-Alcaraz, A., Rodríguez-Malagón, M., MéndeZ-SÁnchez, F. et al. (2011) Island restoration in Mexico: ecological outcomes after systematic eradications of invasive mammals. In Island Invasives: Eradication and Management (eds C.R. Veitch, M.N. Clout \& D.R. Towns), pp. 250-258. IUCN, Gland, Switzerland.

American Ornithologists' Union (1998) Checklist of North and Middle American Birds (7th Edition and Supplements). American Ornithologists' Union, Chicago, USA.

Amori, G. \& Clout, M.N. (2003) Rodents on islands: a conservation challenge. In Rats, Mice and People: Rodent Biology and Management (eds G.R. Singleton, L.A. Hinds, C.J. Krebs \& D.M. Spratt), pp. 63-68. ACIAR Monograph, Canberra, Australia.

Angel, A., Wanless, R.M. \& Cooper, J. (2009) Review of impacts of the introduced house mouse on islands in the Southern Ocean: are mice equivalent to rats? Biological Invasions, 11, 1743-1754.

Bonet, F. \& Rzedowski, J. (1962) La vegetación de las islas del Arrecife Alacranes, Yucatán, México. Anales de la Escuela Nacional de Ciencias Biológicas, 11, 15-59.

Broome, K.G., Brown, D., Cox, A., Cromarty, P., McClelland, P., Golding, C. et al. (2011) Current Agreed Best Practice for Rodent Eradication-Hand Broadcasting Poison Bait (Version 1.3). New
Zealand Department of Conservation internal document DOCDM-8390991. Department of Conservation, Wellington, New Zealand.

Broome, K.G., Cox, A., Golding, C., Cromarty, P., Bell, P. \& McClelland, P. (2014) Rat Eradication Using Aerial Baiting: Current Agreed Best Practice Used in New Zealand (Version 3.o). New Zealand Department of Conservation internal document. Department of Conservation, Wellington, New Zealand.

Broome, K.G., Fairweather, A.A.C. \& Fisher, P. (2012) Brodifacoum Pesticide Information Review. Version 2012/1. Unpublished report docdm-25439. Department of Conservation, Hamilton, New Zealand.

Charruau, P., De La Vega, A.H.D. \& De La Cruz, F.R.M. (2015) Reptiles of Banco Chinchorro: updated list, life history data, and conservation. The Southwestern Naturalist, 60, 299-312.

CONANP (Comisión Nacional de Áreas Naturales Protegidas) (200o) Programa de manejo Reserva de la Biosfera Banco Chinchorro. PCM. INE-SEMARNAT, Mexico City, Mexico. CONANP (Comisión Nacional de Áreas Naturales Protegidas) (2006) Programa de conservación y manejo Parque Nacional Arrecife Alacranes. INE-SEMARNAT, Mexico City, Mexico.

DIISE (2016) The Database of Island Invasive Species Eradications, developed by Island Conservation, Coastal Conservation Action Laboratory UCSC, IUCN SSC Invasive Species Specialist Group, University of Auckland and Landcare Research New Zealand. Http://diise.islandconservation.org [accessed 30 November 2016]. Félix-Lizárraga, M., Jáuregui-García, C., Aguirre-Muñoz, A., Méndez Sánchez, F., Bedolla-Guzmán, Y., Ortiz-Alcaraz, A. et al. (2015) Inventario de vertebrados nativos en las islas Guadalupe, San Benito, Natividad, Asunción, San Roque, Isabel, Marietas, Socorro, Banco Chinchorro y Arrecife Alacranes. Informe final SNIBCONABIO, proyecto No. JF206. Grupo de Ecología y Conservación de Islas, A.C., Mexico City, Mexico.

Fosberg, F.R. (1962) A brief study of the cays of Arrecife Alacran, a Mexican atoll. Atoll Research Bulletin, 93, 1-33.

GECI (Grupo de Ecología y Conservación de Islas) (2015) Rat Eradication on Cayo Centro, Banco Chinchorro, Mexican Caribbean: Operational Plan. Technical report. GECI, Ensenada, Mexico.

Harper, G.A. \& Bunbury, N. (2015) Invasive rats on tropical islands: their population biology and impacts on native species. Global Ecology and Conservation, 3, 607-627.

Harper, G., van Dinther, M. \& Bunbury, N. (2014) Black rats in mangroves: successful and intractable. In 26th Vertebrate Pest Conference (eds R.M. Timm \& J.M. O’Brien), pp. 125-129. University of California, Davis, Kona, Hawaii.

Harper, G.A., van Dinther, M., Russell, J.C. \& Bunbury, N. (2015) The response of black rats (Rattus rattus) to evergreen and seasonally arid habitats: informing eradication planning on a tropical island. Biological Conservation, 185, 66-74.

Harper, G.A., Zabala, J. \& Carrion, V. (2011) Monitoring of a population of Galápagos land iguanas (Conolophus subcristatus) during a rat eradication using brodifacoum. In Island Invasives: Eradication and Management (eds C.R. Veitch, M.N. Clout \& D.R. Towns), pp. 309-312. IUCN, Gland, Switzerland.

Holmes, N.D., Campbell, K.J., Keitt, B.S., Griffiths, R., Beek, J., Donlan, C.J. \& Broome, K.G. (2015) Reporting costs for invasive vertebrate eradications. Biological Invasions, 17, 2913-2925.

Howald, G., Donlan, C.J., Galván, J.P., Russell, J.C., Parkes, J., SAMANIEGO, A. et al. (2007) Invasive rodent eradication on islands. Conservation Biology, 21, 1258-1268.

Jones, H.P., Holmes, N.D., Butchart, S.H.M., Tershy, B.R., KAPPES, P.J., CORKERY, I. et al. (2016) Invasive mammal eradication on islands results in substantial conservation gains. Proceedings of 
the National Academy of Sciences of the United States of America, 113, 4033-4038.

Keitt, B., Griffiths, R., Boudjelas, S., Broome, K., Cranwell, S., Millett, J. et al. (2015) Best practice guidelines for rat eradication on tropical islands. Biological Conservation, 185, 17-26.

NOM (Norma Oficial Mexicana) (2014) NOM-o33-SAG/ZOO. Métodos para dar muerte a los animales domésticos y silvestres. Diario Oficial de la Federación 26-08-2015.

Osborne, P.L. (2000) Tropical Ecosystems and Ecological Concepts. Cambridge University Press, Cambridge, UK.

Pitt, W.C., Berentsen, A.R., Shiels, A.B., Volker, S.F., Eisemann, J.D., Wegmann, A.S. \& Howald, G.R. (2015) Non-target species mortality and the measurement of brodifacoum rodenticide residues after a rat (Rattus rattus) eradication on Palmyra Atoll, tropical Pacific. Biological Conservation, 185, 36-46.

Pott, M., Wegmann, A.S., Griffiths, R., Samaniego-Herrera, A., Cuthbert, R.J., Brooke, M.d.L. et al. (2015) Improving the odds: assessing bait availability before rodent eradications to aid in selecting bait application rates. Biological Conservation, 185, 27-35.

R Development Core Team (2013) R: A Language and Environment for Statistical Computing. R Foundation for Statistical Computing, Vienna, Austria.

Rojas-Mayoral, E., Samaniego-Herrera, A. Méndez-Sánchez, F. \& Aguirre-Muñoz, A. (2016) Rodent eradications for seabird conservation: improving the evaluation of aerial bait dispersion. In 43rd Annual Meeting of the Pacific Seabird Group, Oahu, Hawai'i, USA.

Russell, J.C. (2012) Spatio-temporal patterns of introduced mice and invertebrates on Antipodes Island. Polar Biology, 35, 1187-1195.

Russell, J.C., Binnie, H.R., Oh, J., Anderson, D.P. \& Samaniego-Herrera, A. (2017) Optimizing confirmation of invasive species eradication with rapid eradication assessment. Journal of Applied Ecology, 54, 160-169.

Russell, J.C. \& Broome, K.G. (2016) Fifty years of rodent eradications in New Zealand: another decade of advances. New Zealand Journal of Ecology, 40, 197-204.

Russell, J.C. \& Holmes, N.D. (2015) Tropical island conservation: rat eradication for species recovery. Biological Conservation, 185, 1-7.

Samaniego-Herrera, A. (2014) Ecology and impacts of invasive rodents on tropical islands, in relation to eradication operations. $\mathrm{PhD}$ thesis. The University of Auckland, Auckland, New Zealand.

Samaniego-Herrera, A., Aguirre-Muñoz, A., Méndez-Sánchez, F., Rojas-Mayoral, E. \& Cárdenas-Tapia, A.G. (2015) Pushing the boundaries of rodent eradications on tropical islands: Ship rat eradication on Cayo Centro, Banco Chinchorro, Mexico. 27th International Congress for Conservation Biology, Montpellier, France.

Samaniego-Herrera, A., Aguirre-Muñoz, A., Rodríguez-Malagón, M., Gonzallez-Gómez, R., Torres-García, F., Méndez-Sánchez, F. et al. (2011) Rodent eradications on Mexican islands: advances and challenges. In Island Invasives: Eradication and Management (eds C.R. Veitch, M. N. Clout \& D.R. Towns), pp. 350-355. IUCN, Gland, Switzerland.
Samaniego-Herrera, A., Anderson, D.P., Parkes, J.P. \& Aguirre-Muñoz, A. (2013) Rapid assessment of rat eradication after aerial baiting. Journal of Applied Ecology, 50, 1415-1421.

Samaniego-Herrera, A., Russell, J.C., Choquenot, D., Aguirre-Muñoz, A. \& Clout, M.N. (2014) Invasive rodents on tropical islands: eradication recommendations from Mexico. In Proceedings of the 26th Vertebrate Pest Conference (eds R.M. Timm \& J.M. O'Brien), pp. 43-50. University of California, Kona, USA.

Shiels, A.B., Pitt, W.C., Sugihara, R.T. \& Witmer, G.W. (2014) Biology and impacts of Pacific island invasive species. 11. Rattus rattus, the black rat (Rodentia: Muridae). Pacific Science, 68, 145-184.

Singleton, G.R. \& Krebs, C.J. (2007) The secret world of wild mice. In The Mouse in Biomedical Research (eds J.G. Fox, M.T. Davisson, F.W. Quimby, S.W. Barthold, C.E. Newcomer \& A.L. Smith), pp. 2551. Academic Press, Burlington, USA.

Towns, D.R., Atrinson, I.A.E. \& Daugherty, C.H. (2006) Have the harmful effects of introduced rats on islands been exaggerated? Biological Invasions, 8, 863-891.

Towns, D.R., West, C.J. \& Broome, K.G. (2013) Purposes, outcomes and challenges of eradicating invasive mammals from New Zealand islands: an historical perspective. Wildlife Research, 40, 94-107.

Tunnell, JR, J.W. \& Chapman, B.R. (2000) Seabirds of the Campeche Bank Islands, Southeastern Gulf of Mexico. Atoll Research Bulletin, $482,41-50$.

Wegmann, A., Braun, J. \& Neugarten, R. (2008) Ship rat Rattus rattus eradication on Pein Mal Island, Federated States of Micronesia, Pacific Ocean. Conservation Evidence, 5, 28-32. Wegmann, A., Flint, E., White, S., Fox, M., Howald, G., McClelland, P. et al. (2012) Pushing the envelope in paradise: a novel approach to rat eradication at Palmyra Atoll. In 25th Vertebrate Pest Conference, pp. 48-53. Monterey, USA.

\section{Biographical sketches}

Araceli Samaniego-Herrera's research focuses on efficient management of invasive species, and she oversees the rodent eradication projects of Grupo de Ecología y Conservación de Islas. A Lfonso A GUIRRE-MUÑ Z is interested in interdisciplinary approaches to applied conservation and sustainability. YULIANA BEDOLLA-GUZMÁN is leading an extensive restoration programme focusing on seabirds on Mexican islands. ANA CÁRENAS-TAPIA's interests are the integration of innovative tools, such as geographical information systems and molecular markers, to advance conservation goals. MARí A FÉLIX - LIZÁRRAGA works on conservation and restoration of seabirds on Mexican islands, implementing techniques such as social attraction and habitat management. Federico Méndez-SÁnchez leads GECI's island biosecurity and environmental education programmes. ORLANDO REINA - PONCE contributes to the conservation and protection of wildlife through education and captive management projects. EVARISTO ROJAS-MAYORAL specializes in the development of mathematical models and computational tools to understand the dynamics of ecological systems better. FLOR TORRES-GARCÍA focuses on implementing invasive mammal eradications on Mexican islands. 